\title{
MODELING OF THE DISTRIBUTION PROCESS OF THERMAL HEATONSOUS IN DRYER FOR THERMALABLE PRODUCTS
}

\author{
I. Nykytiuk, S. Lementar, Yu. Veresotskyi \\ National University of Food Technology \\ D. Ryndiuk \\ National Technical University of Ukraine "Igor Sikorsky Kyiv Polytechnic Institute"
}

\begin{tabular}{l}
\multicolumn{1}{c}{ Key words: } \\
Fluidized layer \\
Gas distributor \\
Thermolabile products \\
Casein \\
\hline \multicolumn{1}{c}{ Article history: } \\
Received 17.01.2018 \\
Received in revised form \\
05.01.2018 \\
Accepted 06.02.2018 \\
\hline
\end{tabular}

Corresponding author:

I. Nykytiuk

E-mail:

npnuht@ukr.net

\begin{abstract}
Efficiency of the drying process of food products in the fluidized state is largely determined by the gas-dynamic parameters of the heat transfer agent flow, which, in turn, depends on the design of the gas-distributor.

The main task of the gas-distributor in dryers with fluidized state is to provide uniform and constant parameters of the product layer without falling product particles into the sublayer space and to ensure the protection of the gas distribution grid from the negative impact of the product.

This is especially important when occur high-temperature processes with substances that are temperature sensitive, such as casein, which can soften and stick to the grid, increasing its resistance, up to the stop of the process.

In order to find the rational design of the gas-distributor, we performed a computer simulation of the distribution of heat transfer agent in a drying plant for casein. In the simulation, computational fluid dynamics (CFD) methods were used.

Based on the simulation results, a new design of a gas-distributor with adjustable elements was proposed. It was found that the hydraulic resistance of this gas-distributor is $221 \mathrm{~Pa}$, which is significantly less than the resistance in a classic stationary gas-distributor with prismatic elements $(4952 \mathrm{~Pa})$.

In the modernized design of the gas-distributor, the heat transfer agent velocity in the fluidized layer is about 5-6 $\mathrm{m} / \mathrm{s}$, which corresponds to the recommendations for the creation of a stable fluidized-state product layer during the casein drying.

Consequently, with the same initial parameters of heat transfer agent, the new design of the gas-distributor provides better conditions for casein drying than with a stationary gas-distributor.
\end{abstract}

DOI: $10.24263 / 2225-2924-2018-24-1-21$ 


\section{МОДЕЛЮВАННЯ ПРОЦЕСУ РОЗПОДІЛЕННЯ ТЕПЛОНОСІЯ В СУШАРЦІ ДЛЯ ТЕРМОЛАБІЛЬНИХ ПРОДУКТІВ}

\section{І.І. Никитюк, С.Ю. Лементар, Ю.І. Вересоцький Національний університет харчових технологій}

Д.В. Риндюк

Національний технічний університет Украӥни «Київський політехнічний інститут ім. І. Сікорського»

Ефективність прочесу сушіння харчових продуктів у псевдозрідженому шарі визначається газодинамічними параметрами потоку теплоносія, який, у свою чергу, залежить від конструкиії газорозподільника.

Основне завдання газорозподільника в сушарках з псевдозрідженим шаром забезпечення рівномірних і сталих параметрів шару продукту без попадання частинок продукту в підрешітковий простір $i$ забезпечення захисту газорозподільної решітки від негативного впливу з боку продукту.

Це особливо важливо при проведенні високотемпературних процесів $з$ речовинами, чутливими до впливу температури, наприклад, казеїном, які можуть розм'якшуватись $і$ налипати на решітку, збільшуючи ії опір, аж до зупинки прочесу.

3 метою знаходження раціональної конструкиії газорозподільника виконано комп'ютерне моделювання розподілу теплоносія в сушильній установиі для казеӥну. При моделюванні використовувалися методи обчислювальної гідродинаміки (Computational Fluid Dynamics, CFD).

На основі результатів моделювання запропоновано нову конструкиію газорозподільника з регульованими елементами. Виявлено, щчо гідравлічний опір цього газорозподільника складає 221 Па, щзо суттєво менше за опір у класичному нерухомому газорозподільнику з призматичними елементами (4952 Па). Також у модернізованій конструкиї̈ газорозподільника швидкість теплоносія в завислому шарі становить близько 5-6 м/с, що відповідає рекомендаціям щоодо створення стійкого псевдозрідженого шару продукту при сушінні казеїну.

Отже, при однакових початкових параметрах подачі теплоносія нова конструкиія газорозподільника забезпечуе кращі, ніж у нерухомому газорозподільнику, умови для висушування казеїну.

Ключові слова: псевдозріджений шар, газорозподільник, термолабільні продукти, казеїн.

Постановка проблеми. Застосування сушки харчових продуктів у псевдозрідженому шарі дає змогу проводити цей процес при високих швидкостях, що важливо не тільки для підвищення техніко-економічних показників сушильних установок, а й для збереження якості багатьох термолабільних продуктів, оскільки при тривалій термічній обробці вона може значно погіршитися.

Наприклад, тривалість сушіння казеїну у псевдозрідженому шарі знижується у 1,5 раза порівняно із сушінням у нерухомому шарі та у 8 разів в 
умовах вакууму і становить 30 хвилин при температурі сушіння $100^{\circ} \mathrm{C}$ до кінцевого вологовмісту 10\% [1].

Швидкість проходження тепломасообмінних процесів у псевдозрідженому шарі істотним чином визначається його газодинамічними особливостями. Тому ефективність роботи апаратів для сушіння матеріалів у псевдозрідженому шарі значною мірою залежить від параметрів потоку газу, який утримує цей шар. Ці параметри також істотно впливають на профіль температур і концентрацій дисперсної (твердої) фази в зоні сушіння. Визначення газодинамічних умов руху газового потоку забезпечує можливість математичного опису швидкості руху та часу перебування твердих частинок у сушильному апараті [2].

У промислових сушарках, які працюють в умовах псевдозрідженого шару продукту, розподіл потоку сушильного агента (тобто газу, який одночасно й утримує цей шар) здійснюється за допомогою газорозподільного пристрою. Тому знаходження раціональних конструкційних параметрів систем розподілення сушильного агента, зокрема газорозподільних пристроїв як основного їх компонента, є актуальним завданням.

Аналіз останніх досліджень і публікацій. Сучасні вимоги до проектування новітнього сушильного обладнання передбачають впровадження малогабаритних апаратів з широким спектром застосування, високою питомою потужністю, що відрізняються простотою виготовлення, монтажу, експлуатації й обслуговування. Різноманітність конструкцій апаратів 3 псевдозрідженим шаром обумовлена умовами їх використання, особливостями перебігу в них тепломасообмінних процесів, газо- й термодинамічних умов у кожному конкретному випадку застосування цього виду обладнання. Значна кількість наукових дослідженнь псевдозрідженого шару спрямована на інтенсифікацію тепломасообміну в псевдозрідженому шарі, підвищенню його газодинамічної стабільності та теоретичному опису цих процесів [2-5].

Здійснення й ефективність сушіння в псевдозрідженому шарі суттєво залежать від конструкції апарата, а тому апаратурне оформлення має щонайкраще відповідати агрегатному стану вихідного матеріалу, його фізико-хімічним і структурно-механічним властивостям, а також необхідним показникам продуктивності установки та якості готового продукту. Відома велика кількість конструкцій сушарок із псевдозрідженим шаром, що дає змогу зробити цілком обгрунтований вибір для досягнення тих чи інших цілей [3].

Сьогодні багато уваги приділяється розробленню i порівнянню нових конструкцій газорозподільних пристроїв сушарок 3 псевдозрідженим шаром 3 метою пошуку оптимальних. Накопичений при цьому досвід показує, що багато деталей цих конструкцій істотно залежать від характеру технологічного процесу i властивостей псевдозрідженої твердої фази, тому не можна рекомендувати якийсь певний тип газорозподільника як бажаний для всіх продуктів [4].

Час перебування частинок у зоні сушіння i температура сушильного агента $\epsilon$ важливими параметрами при сушінні термолабільних продуктів, оскільки відбувається суттєве зниження їх якості, якщо частинки залишаються в потоці повітря занадто довго або температура потоку теплоносія занадто висока. Тому схема розподілу повітряних потоків за допомогою газорозподільного пристрою всередині сушарки 3 псевдозрідженим шаром 
вважається одним із основних факторів, які підлягають детальному вивченню та моделюванню. Також важливою причиною необхідності проведення таких досліджень є забезпечення уникнення застійних зон у зоні сушіння.

На основі результатів проведених досліджень можна буде надати рекомендації щодо розробки конструкщії газорозподільного пристрою 3 рухомими елементами, що дасть змогу змінювати газодинамічні показники потоку теплоносія для забезпечення сталого процесу сушіння при зміні вхідних параметрів продукту.

Мета дослідження: знаходження раціональних параметрів конструкції газорозподільного пристрою в установці для сушіння казеїну шляхом моделювання потоків теплоносія.

Викладення основних результатів дослідження. Як зазначено вище, реалізація процесу сушіння продукту в псевдозрідженому шарі визначається режимом газодинаміки, яка залежить від конструкції газорозподільника.

Основне завдання газорозподільника - забезпечення рівномірних і сталих параметрів псевдозрідженого шару продукту без провалу частинок у підрешітковий простір і формування надрешіткової зони продукту таким чином, щоб захистити газорозподільні решітки від термічних та інших негативних впливів зі сторони самого псевдозрідженого шару. Остання обставина особливо важлива при проведенні високотемпературних процесів із термолабільними матеріалами, які можуть розм'якшуватись і налипати на решітки, збільшуючи опір останньої аж до повної зупинки процесу [3].

Сушарка, яка прийнята за типову для проведення процесу зневоднення продукту, має прямокутну форму перерізу і складається з рами із завантажувальним пристроєм, статично нерухомого газорозподільного пристрою, сушильної й охолоджуючої камер.

Недоліком сушарки $є$ те, що існуюча конструкція газорозподільного пристрою (рис. 1.), який виконано у вигляді паралельно установлених призматичних елементів з розширеною основою, є нерухомою і не дає змоги оперативно змінювати параметри потоку теплоносія при зміні вхідних параметрів продукту.

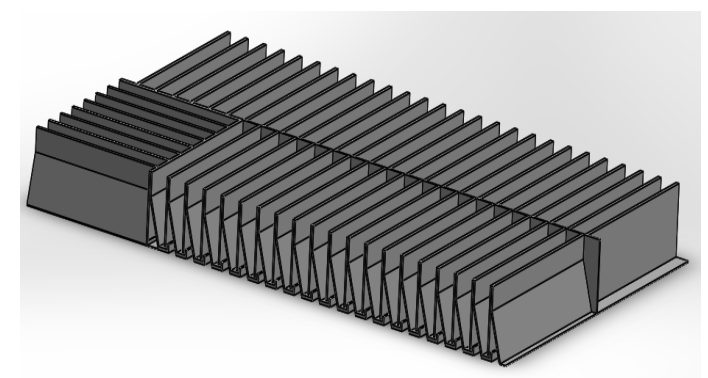

Рис. 1. Газорозподільний пристрій $з$ нерухомими елементами

Завдяки моделюванню потоків теплоносія через газорозподільник було 3'ясовано, що існуюча конструкція створює значний гідравлічний опір, який досягає 4952 Па (рис. 2a), що безпосередньо впливає на збільшення енерго- 
затрат у сушарці, а також створює істотні перепади швидкості потоку теплоносія (рис. 2б).

Швидкість теплоносія в зоні сушіння досягає 9-10 м/с, що значно перевищує рекомендовані параметри при сушінні казеїну [1].

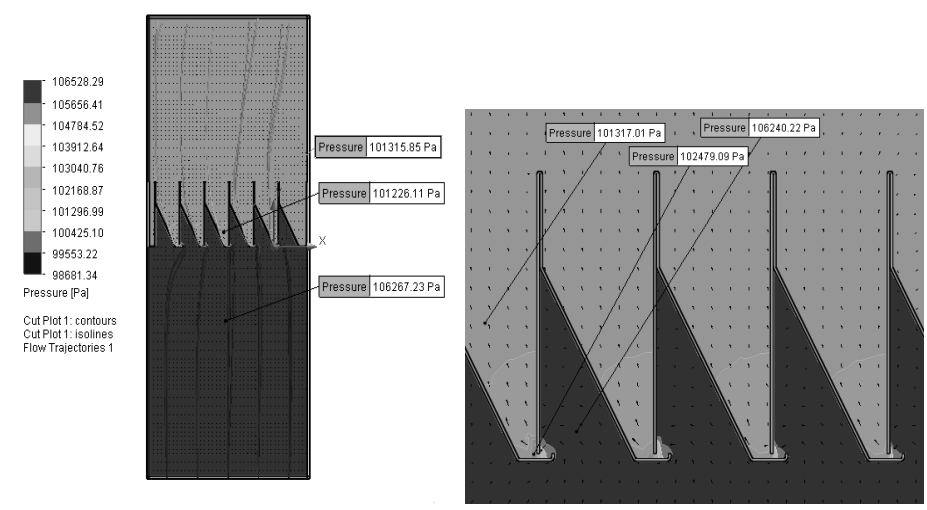

a)
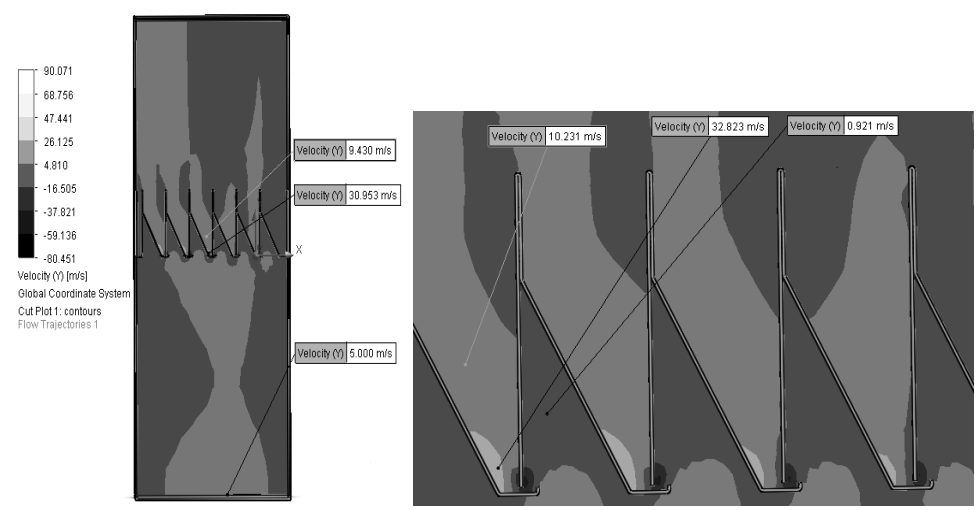

б)

Рис. 2. Розподіл тиску (а) та швидкості (б) теплоносія в сушильній камері

Після проведення відповідних проектних розрахунків, а також моделювання процесу подачі і розподілення теплоносія за допомогою систем комп'ютерного моделювання з використанням методів обчислювальної гідродинаміки (Computational Fluid Dynamics, CFD), було запропоновано удосконалену конструкцію газорозподільного пристрою (рис. 3), який забезпечить регулювання газодинамічних параметрів потоку теплоносія.

Модернізований газорозподільний пристрій виконано у вигляді набору пластин, фіксованих за допомогою вилок, які мають можливість приймати відповідний кут нахилу, що здійснюється за допомогою додаткового механічного приводу, який включає в себе кроковий двигун.

Позитивний ефект від застосування газорозподільника такої конструкції полягає в можливості збільшення площі активної поверхні теплообміну між теплоносієм і продуктом за рахунок зменшення об'єму застійних зон, підви- 
щення однорідності псевдозрідженого шару продукту, поліпшення якості висушеного продукту та зменшення часу перебігу процесу.

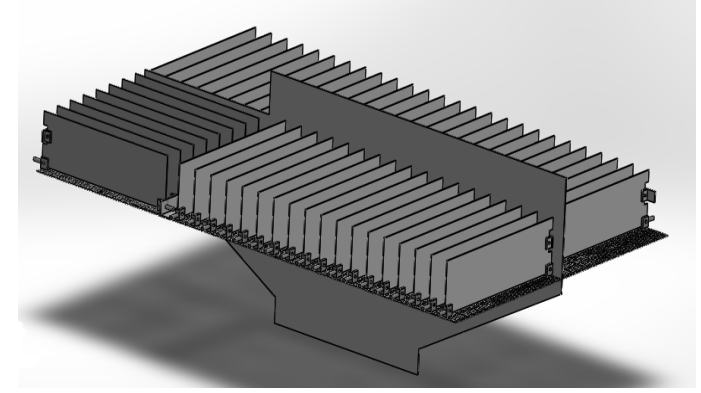

Рис. 3. Газорозподільний пристрій із регульованими елементами

Розподіл результуючої швидкості й тиску теплоносія для різних кутів нахилу лопатей газорозподільника наведено на рис. 4.
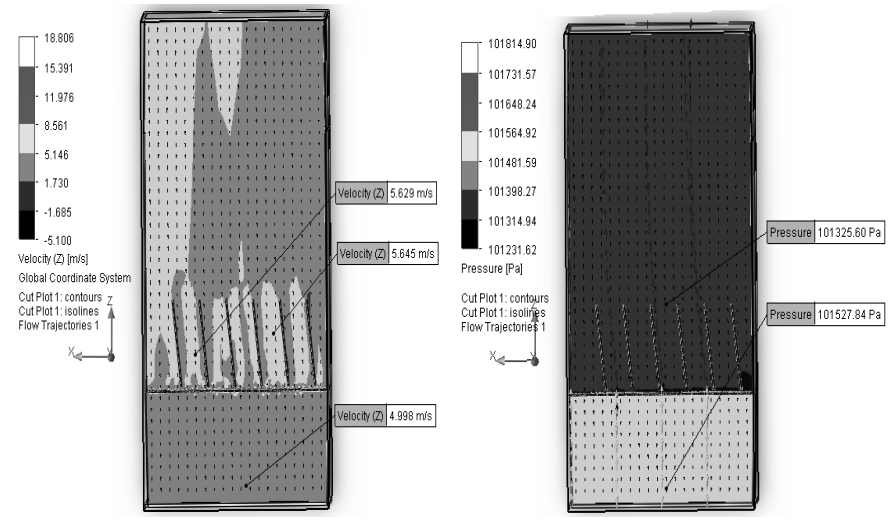

a)
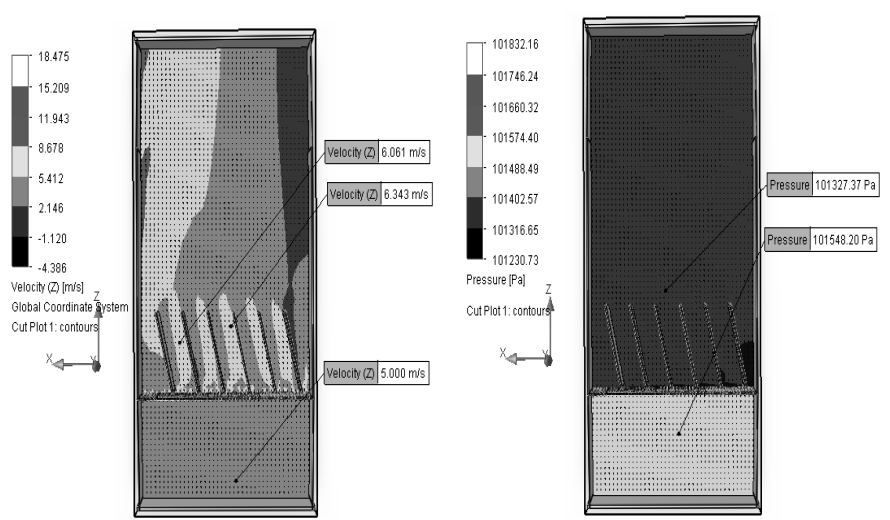

б)

Рис. 4. Розподіл швидкості та тиску теплоносія при куті нахилу пластин газорозподільника $10^{\circ}$ (a) і $20^{\circ}$ (б) 
Результати моделювання (рис. 4) показують, що характер розподілу швидкості й тиску теплоносія в запропонованій конструкції газорозподільника значно відрізняється від цих же показників у нерухомому газорозподільнику. Гідравлічний опір модернізованого газорозподільника склав лише 221 Па, що значно менше порівняно з базовою конструкцією (4952 Па). Також у запропонованій конструкції спостерігається встановлення швидкості теплоносія в псевдозрідженому шарі близько 5-6 м/с, що відповідає рекомендаціям щодо швидкості теплоносія для створення стійкого шару при сушінні казеїну [1].

Результати досліджень комп'ютерного моделювання дали змогу встановити характерні особливості газодинамічної картини в робочому просторі апарата, виявити наявність областей зниженої швидкості, інтенсивного вихроутворення, сепарації тощо. Застосовуючи такий підхід до вивчення газодинаміки руху потоків, можна виявити конструктивні недоліки сушарки й усунути їх на стадії проектування дослідного зразка, що скорочує собівартість розробки нового обладнання.

\section{Висновки}

У результаті моделювання модернізованого газорозподільного пристрою зі змінним кутом лопатей виявлено, що:

- гідравлічний опір конструкції газорозподільника значно нижчий від опору класичного нерухомого газорозподільника, що сприяє зменшенню енергозатрат на перебіг процесу;

- спостерігається встановлення раціональної швидкості теплоносія (56 м/с) для підтримання сталого шару казеїну;

- збільшується активна площа контакту сушильного агента з висушуваним продуктом, що сприяє зменшення часу перебігу процесу.

Отже, запропонована конструкція газорозподільного пристрою забезпечує кращі, порівняно з базовим варіантом, умови для висушування продукту в сушарках $з$ псевдозрідженим шаром.

\section{Література}

1. Чабанова О.Б. Дослідження процесу сушіння харчового казеїну / О.Б. Чабанова, Т.В. Недобійчук, Д.О. Скрипніченко / Наукові праці ОНАХТ. - 2010. - Т. 2, № 38. C. $274-281$.

2. Маренок В.М. Вихревой псевдосжиженный слой и его практическое применение / В.М. Маренок, В.И. Склабинский // Физика аэродисперсных систем. - 2004. — № 2. C. 86-93.

3. Сажин Б.С. Выбор и расчет аппаратов с взвешенным слоем / Б.С. Сажин, В.Б. Сажин, М.Б. Сажина. - Москва : РОСЗИТЛП, 2001. — 336 с.

4. Научные основы техники сушки термолабильных материалов / А.И. Леонтьева, К.В. Бряикин, А.А. Дегтярев, В.С. Орехов. - М.: Изд. дом «Академия Естествознания», 2011. - $100 \mathrm{c}$.

5. Якуба О.Р. Інтенсифікація процесу сушіння харчових продуктів / О. Р. Якуба, М.Ю. Савченко // Вісник СНАУ. Серія тваринництво. — 2006. - № 10. - С. 140-144. 